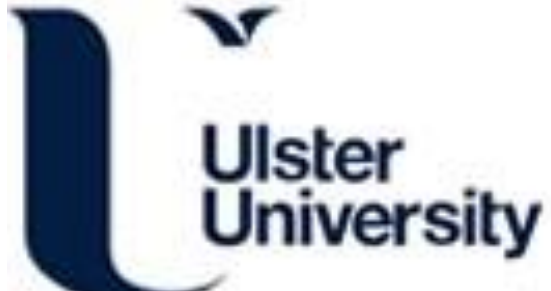

\section{Seasonal and episodic variability in the morphodynamics of an ephemeral inlet, Zinkwazi Estuary, South Africa}

Bond, J. K., Green, A. N., Cooper, A., \& Humphries, M. S. (2013). Seasonal and episodic variability in the morphodynamics of an ephemeral inlet, Zinkwazi Estuary, South Africa. Journal of Coastal Research, SI 65, 446-451.

Link to publication record in Ulster University Research Portal

\section{Published in:}

Journal of Coastal Research

Publication Status:

Published (in print/issue): 01/01/2013

\section{Document Version}

Publisher's PDF, also known as Version of record

\section{General rights}

Copyright for the publications made accessible via Ulster University's Research Portal is retained by the author(s) and / or other copyright owners and it is a condition of accessing these publications that users recognise and abide by the legal requirements associated with these rights.

\section{Take down policy}

The Research Portal is Ulster University's institutional repository that provides access to Ulster's research outputs. Every effort has been made to ensure that content in the Research Portal does not infringe any person's rights, or applicable UK laws. If you discover content in the Research Portal that you believe breaches copyright or violates any law, please contact pure-support@ulster.ac.uk. 


\title{
Seasonal and episodic variability in the morphodynamics of an ephemeral inlet, Zinkwazi Estuary, South Africa
}

\author{
J. Bond $\uparrow \#$, A.N. Green $\uparrow$, J.A.G Cooper $\dagger$ t, M.S. Humphries $\infty$
}

$\dagger$ Geological Sciences

School of Agricultural, Earth and

Environmental Sciences,

University of KwaZulu-Natal,Westville,

Private Bag X54001, South Africa

Greena1@ukzn.ac.za

\# Golder Associates, Block C,

Bellevue Campus,

5 Bellevue Road, Kloof, 3610,

South Africa

jonobond@gmail.com

\author{
\$ School of Environmental Sciences, \\ Centre for Coastal and Marine Research, \\ University of Ulster, Cromore Road, \\ Coleraine BT52 1SA, UK \\ JAG.Cooper@ulster.ac.uk
}

$\infty$ Molecular Sciences Institute, School of Chemistry

University of the Witwatersrand

Private Bag 3,Wits 2050, Johannesburg,

South Africa

marchump@gmail.com

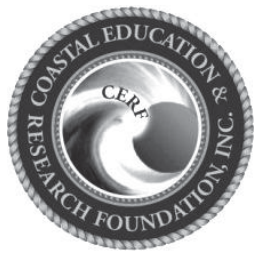

www.cerf-jcr.org

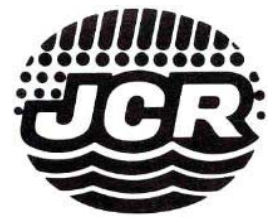

www.JCRonline.org

\section{ABSTRACT}

Bond, J., Green, A.N., Cooper, J.A.G. and Humphries, M.S., 2013. Seasonal and episodic variability in the morphodynamics of an ephemeral inlet, Zinkwazi Estuary, South Africa. In: Conley, D.C., Masselink, G., Russell, P.E. and O'Hare, T.J. (eds.), Proceedings $12^{\text {th }}$ International Coastal Symposium (Plymouth, England), Journal of Coastal Research, Special Issue No. 65, pp. 446-451, ISSN 0749-0208.

\begin{abstract}
The inlet dynamics of estuary and lake systems with ephemeral inlets have been little studied compared to systems with semi-permanent tidal inlets. Here we document the meso-scale dynamics of a barrier and its associated ephemeral inlet. The inlet is typically open during the rainy season and experiences closure during winter low flow periods. It does not migrate. The inlet is formed by fluvial overtopping of the barrier and when active, forms a small delta seaward of the channel and a small flood tide delta in the back-barrier. The tidal prism is insufficient to maintain the inlet and it is quickly sealed through wave-reworking of sand from the ephemeral delta when fluvial discharge diminishes. During a large ocean swell event coupled with abnormally high tides in 2007, a departure from this seasonal behaviour occurred. The barrier migrated $100 \mathrm{~m}$ landwards and formed a gently $\left(1.74^{\circ}\right)$ seaward dipping sand sheet. Whereas the barrier had previously been narrow, it was widened by 80 $\mathrm{m}$ and rose $1.5 \mathrm{~m}$ in elevation. A breach later occurred and rapidly migrated northwards, establishing a significantly deeper inlet. This closed following wave reworking of a large ephemeral delta. Since then the barrier has maintained its landward position yet the inlet has continued to function as it did prior to the storm surge. This episodic barrier retreat appears to represent crossing of a morphodynamic threshold that triggered historically unprecedented rates of barrier rollover, creating a new set of inlet morphodynamic processes. These were short-lived and the system appears to have reverted to the typical seasonal morphodynamic processes despite such rapid rollover.
\end{abstract}

ADDITIONAL INDEX WORDS: Ephemeral inlets, morphodynamic threshold, barrier rollover, storm surge

\section{INTRODUCTION}

The dynamics of ephemeral inlets have been relatively understudied in comparison to the semi-permanently open inlets from which the bulk of the literature concerning inlet/barrier behavior has stemmed. Many of these features exhibit unusual behaviour (e.g. Green et al., 2012) not typically included in the models of barrier and inlet dynamics proposed by Davis and Hayes (1984) and elaborated on by FitzGerald and Nummedal (1983), FitzGerald (1996) and FitzGerald et al. (2002).

The east coast of South Africa is characterized by an abundance of estuaries with ephemeral inlets. Cooper (2001) considers many of these to be river-dominated estuaries. In river-dominated

DOI: 10.2112/SI65-076.1 received 07 December 2012; accepted 06 March 2013.

(c) Coastal Education \& Research Foundation 2013 estuaries fluvial sedimentation extends to the coastal barrier (Cooper, 1993). These systems consequently have a small tidal prism and maintain a surface water connection (inlet) with the ocean only through fluvial discharge. Flood-tide deltas are poorly developed and ebb deltas are restricted by high wave energy. Their morphology thus differs from 'typical' tidal inlets (Cooper, 2001). Periods of low fluvial discharge cause river-dominated inlets to close through onshore and longshore transport of littoral sand into the inlet. Inlets remain closed until opened by increased fluvial discharge or occasionally by channels cut by wave overwashing which cause elevated water levels to be emptied (Cooper, 2001).

Such estuaries and their barriers may respond to sea-level rise in three different ways. Firstly by erosion, often referred to as the Bruun model (Bruun, 1962) where barrier sediment eroded during sea level rise is deposited offshore. Secondly, by rollover where 
sediment is transported landwards and barriers translate as discrete entities through the mechanism of overwash (Cooper, 2007). Lastly by overstepping where in-place coastal drowning of the shore profile occurs (Rampino and Sanders, 1980; 1982). The subdued elevations and overall narrow nature of the barriers associated with many South African river-dominated estuaries predispose these features to overwashing and the eventual rollover of the barrier form. Here we present the case of a barrier that has experienced rapid rollover. We aim to investigate how this rollover has affected the morphodynamics of both the inlet and barrier in light of the meso-scale processes that control the inlet function and form.

\section{SETTING}

This study focuses on the river-dominated Zinkwazi Estuary on the KwaZulu-Natal coast of South Africa (Fig. 1). The coast faces the Indian Ocean and experiences a swell-dominated wave regime and a spring tidal range of $1.84 \mathrm{~m}$. Mean Hs is $1.59 \mathrm{~m}$ (Moes and Roussouw, 2008). Storm-driven swells during March 2007 had a significant wave height of $8.5 \mathrm{~m}$ (Moes and Roussouw, 2008) and a period of 16.6s (Salzmann and Green, 2012) as measured from the National Ports Authority's wave rider buoy offshore Richards Bay (Fig. 1). The associated storm surge resulted in significant quantities of marine sediment being deposited in the back-barriers of most of KwaZulu-Natal's estuaries (Smith et al., 2010). The dominant wave approach is from the SE with a smaller subordinate ENE component (Roussouw, 1989). Occasional deep ocean swells from the S and the SW are rare (Cooper, 1991). The coastline orientation is $042^{\circ}-222^{\circ}$ with a northerly longshore transport direction. Longshore transport is enhanced during the winter swell regime (Smith et al., 2010) and the annual longshore transport volume was calculated at 500,000 $\mathrm{m}^{3}$ at Richards Bay, $100 \mathrm{~km}$ north of the study area (Schoonees, 2000).

Rivers of the KZN coastline drain a steep hinterland with an average gradient greater than 1:100 (Cooper, 1990). Fluvial sediment supply is consequently high. The Zinkwazi River catchment is small $\left(\sim 75 \mathrm{~km}^{2}\right)$ and incises into deeply weathered Pleistocene soils (McCormick, Cooper and Mason, 1992). Despite its small catchment size, it has a mean annual run off of $14.3 \times 10^{6}$ $\mathrm{m}^{3}$ (Chew and Bowen, 1971) with an estimated sediment yield of 29200 tonnes per year (Rooseboom, 1975).

The coastline comprises crenulate bays bound to the south by rocky headlands around which the southeasterly swell refracts. The Zinkwazi Estuary inlet typically occurs in the wave-shadow of one of these rocky headlands. The estuary is located in a headland-embayment cell, with the sandy barrier assuming a swash-aligned morphology. The degree of fluvial discharge controls the extent to which the estuary remains open to the Indian Ocean; the small tidal prism has little effect on maintaining an opening for any substantial period of time.

\section{METHODS}

The mesoscale evolution of the Zinkwazi Estuary was examined using aerial photography spanning the years 1937, 1959, 1967, 1973, 1983, 1989, 1997, 2000, and 2004. These were polynomially geo-referenced to the GCS_Cape datum with an RMS error of 10-15 m. These data were supplemented by later Google Earth ${ }^{\mathrm{TM}}$ satellite images (2010 and 2011) and a series of topographic surveys of the Zinkwazi barrier and inlet.

The estuary barrier was surveyed on six occasions (12/8/2006 2/11/2006, 24/11/2006, 28/02/2007, 24/03/2007, and 5/5/2007) using a dumpy level and staff (centimetre accuracy). All survey points were benchmarked to MSL. The survey data were then interpolated using the nearest neighbor technique in ARCGis 9.1

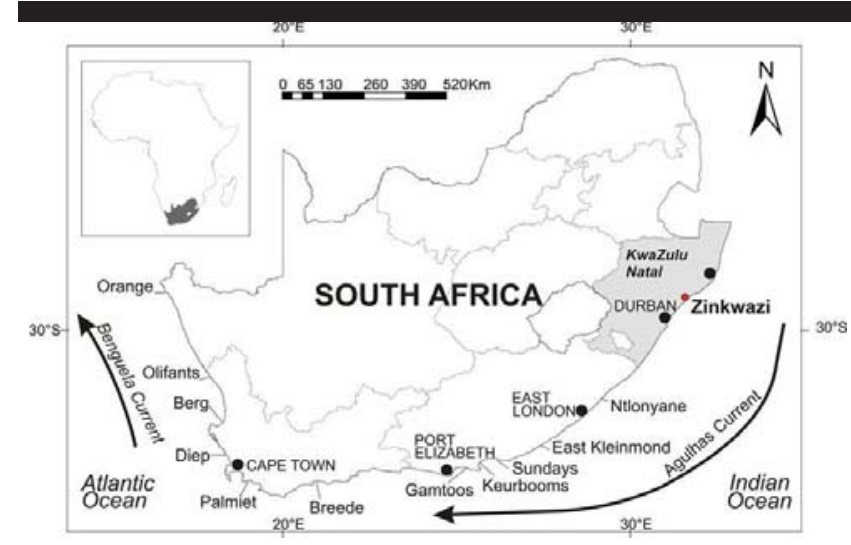

Figure 1. Location of study area in relation to other major South African estuaries with ephemeral inlets.

to create digital elevation models illustrating time sequence morphological change to the inlet and barrier. Open/closed inlet states were monitored on a monthly basis from 1976 by Begg (1978) and further bolstered by local resident observations (Achtzehn, H.G pers comm).

\section{RESULTS}

Over a 32 year period from 1976 to 2007 the Zinkwazi Estuary was on average open $20 \%$ of the year (Fig. 2). The inlet opened on average 4 times annually and for approximately 18 days at a time. The longest the system remained open for was 74 days (recorded in 2001); alternatively it has remained closed for up to an entire year (1992 and 2003). Breaching occurs predominantly in summer (75\%) and an open mouth state is generally maintained for longer. Artificial breaching of the mouth was recorded on 15 occasions from 1976 to 1994, but represents less than 1\% of total openings.

\section{Mesoscale morphodynamics 1937-2004}

The earliest set of aerial photography reveals that a single channel dominated the system, separated from the ocean by a $\sim 75$ $m$ wide barrier with the inlet closed to the ocean. The barrier was densely colonised by coastal forest at both its northern and southern extents (Fig. 3). Two large overwash fans had been deposited into the back-barrier environment, extending $\sim 25 \mathrm{~m}$

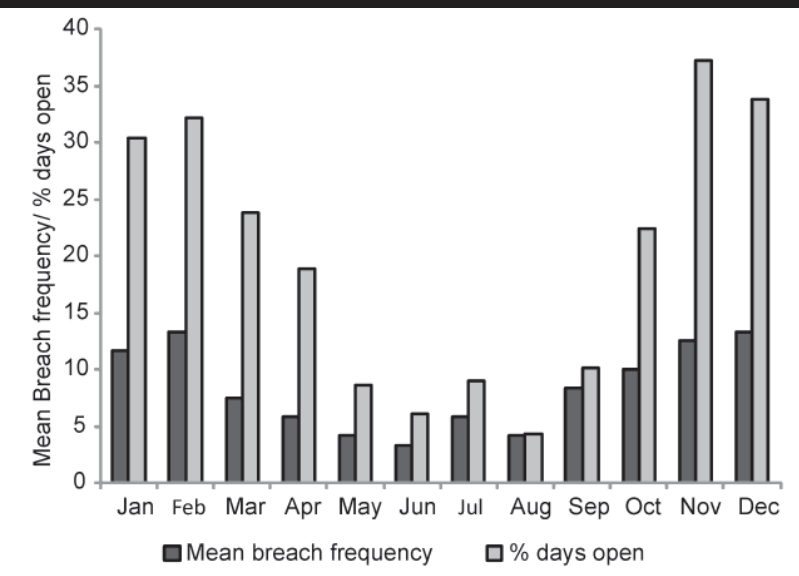

Figure 2. Average monthly breach frequency (1976-2007) showing average \% days open. 

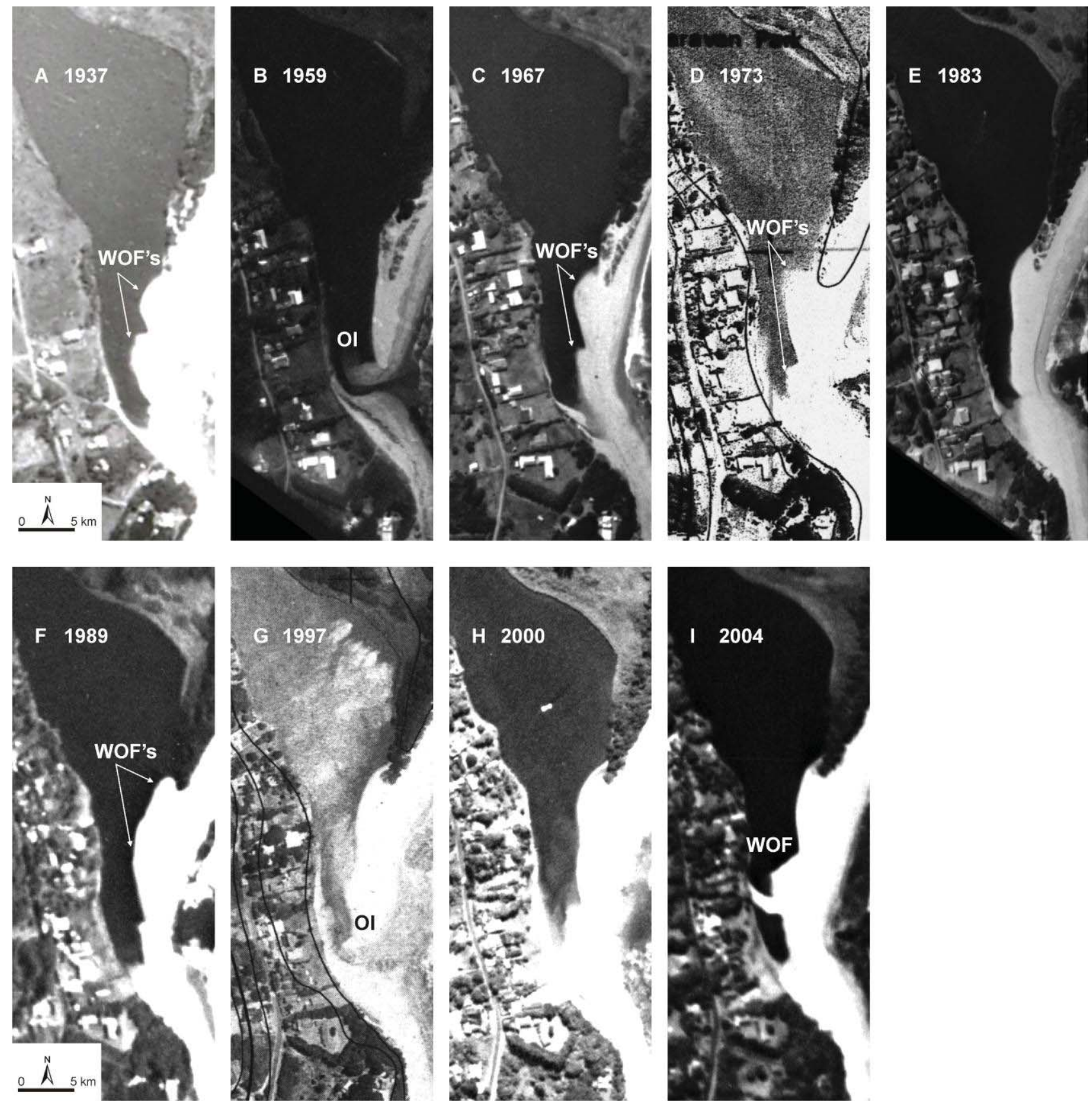

Figure 3. Time sequence aerial photography of the Zinkwazi barrier and inlet spanning 1937 to 2004. A. Closed state in 1937 with wash over fans (WOF's). B. Open inlet (OI) in 1959 with recurved spit and planform backbarrier shoreline. C. Closed state in 1967 with WOF's. D. Closed state in 1973 with WOF's. E. Closed state in 1983 with planform backbarrier shoreline. F. Closed state 1989 with WOF's. G. Open state in 1997 with subdued WOF's. H. Closed state in 2000 with WOF's. I. Closed state in 2004 with WOF's.

\section{landwards.}

By June 1959, the interface between the estuary and barrier had achieved a linear form, suggesting that erosion along this margin had removed the overwash fans. The inlet was open in the southernmost section of the barrier and the dune vegetation had retreated to the north suggesting that the previously vegetated areas in the south had been obliterated by overwash. The northern side of the inlet had formed a recurved spit with a poorly formed flood tide delta. The barrier was $\sim 20$ m wide at its narrowest point (Table 1).

Aerial photography from 1967 reveals that the inlet was closed and several large washover fans had entered the estuary. These extended $\sim 30 \mathrm{~m}$ into the back-barrier areas and appeared to have plugged the old inlet and widened the barrier by $40 \mathrm{~m}$ (Table 1). By June 1973, several washover fans had amalgamated and the barrier had widened by $\sim 20 \mathrm{~m}$. The inlet was closed at this point. 
Table 1. Overview of the mesoscale changes to barrier width.

\begin{tabular}{llll}
\hline \hline Year & Barrier Width & Net change & Inlet state \\
$\mathbf{1 9 3 7}$ & $75 \mathrm{~m}$ & N/A & Closed \\
$\mathbf{1 9 5 9}$ & $20 \mathrm{~m}$ & $-35 \mathrm{~m}$ & Open \\
$\mathbf{1 9 6 7}$ & $60 \mathrm{~m}$ & $+40 \mathrm{~m}$ & Closed \\
$\mathbf{1 9 7 3}$ & $80 \mathrm{~m}$ & $+20 \mathrm{~m}$ & Closed \\
$\mathbf{1 9 8 3}$ & $45 \mathrm{~m}$ & $-35 \mathrm{~m}$ & Closed \\
$\mathbf{1 9 8 9}$ & $65 \mathrm{~m}$ & $20 \mathrm{~m}$ & Closed \\
$\mathbf{1 9 9 7}$ & $70 \mathrm{~m}$ & $5 \mathrm{~m}$ & Open \\
$\mathbf{2 0 0 0}$ & $90 \mathrm{~m}$ & $20 \mathrm{~m}$ & Closed \\
$\mathbf{2 0 0 4}$ & $90 \mathrm{~m}$ & $0 \mathrm{~m}$ & Closed \\
\hline & Average width & Maximum & \\
& $66 \mathrm{~m}$ & net change & \\
& & $\leq 40 \mathrm{~m}$ & \\
\hline
\end{tabular}

By 1983, old washover fan material had once more been reworked into a linear planform layout. The inlet was closed and the barrier had narrowed by $\sim 35 \mathrm{~m}$ in its southernmost portions. In its narrowest portions, the barrier reached a width of $\sim 45 \mathrm{~m}$ (table 1). This had widened to $\sim 65 \mathrm{~m}$ by July 1989. At this point the barrier shows several small washover fans that had begun to be reworked by wind-waves in the back-barrier. In October 1997, the estuary was open at its southern margin (Table 1).

The barrier had migrated landward along the rocky headland by $\sim 75 \mathrm{~m}$ and a small, narrow $(<10 \mathrm{~m})$ inlet was established adjacent to the rocky headland where the barrier had thinned. Two washover fans are evident in the back-barrier.

By 2000, the barrier had fully re-established itself with the inlet closing and the barrier being widened by almost $20 \mathrm{~m}$ (Table 1). Several washover fans were in the process of being reworked into planform shape in the back-barrier. By June 2004, landward migration of the barrier had occurred at the barrier's northern and central extents with significant washover fans having been deposited up to $30 \mathrm{~m}$ into the back-barrier areas.

\section{Pre- and post-storm surge barrier/inlet dynamics 2006-2007}

Time series survey data of the barrier show marked changes to the barrier and back-barrier environments after the storm surge of March 2007. The pre-March 2007 surveys showed an 60 m wide barrier that both widened and increased in crest elevation northwards (Fig 4A-D). The barrier width varied significantly over the survey period prior to March 2007. Between August and November 2006 the barrier narrowed from 60m (Fig. 4A) to $40 \mathrm{~m}$ (Fig. 4B). By the end of November 2006 it had widened to $65 \mathrm{~m}$ (Fig. 4C). The last survey prior to March 2007 showed a foreshore with several beach cusps and a narrow barrier (30 m) (Fig. 4D). Successive breaching during the wet season between November 2006 and February 2007 had formed a wide and shallow depression to the south where the successive inlets had previously been established. Inlets here are restricted to a maximum depth of incision of $0.5 \mathrm{~m}$ MSL due to bedrock.

Post-March 2007, the barrier had migrated landwards by $100 \mathrm{~m}$, forming a gentle $\left(1.74^{\circ}\right)$, seaward-sloping sand sheet with a single, $200 \mathrm{~m}$ wide overwash fan. The southern extent of the barrier, usually marked by the presence of an inlet, was significantly elevated (> $2.5 \mathrm{~m}$ MSL) above that of the highest seasonal elevation. Where the barrier was formerly at its narrowest it had widened by $80 \mathrm{~m}$ (Fig. 4E).

The inlet remained closed for 32 days until it was artificially breached in its usual inlet position to avoid back-barrier flooding. At this point the inlet behavior began to significantly depart from its typical seasonal behavior. Sustained ebb flow from the storm- derived hydraulic head scoured the channel to bedrock at the headland. This impeded flow causing the inlet to migrate north forming a deeper inlet mid-way along the barrier in a previously unoccupied position (Fig. 4F). Incision was no longer restricted by bedrock and an inlet depth below MSL was established. The southern outlet remained inactive and the new inlet enabled the system to rapidly drain the back-barrier waters within 6 days. This inlet had all but closed by 5/5/2007 (Fig. 4F).

Since 2007, the barrier has roughly maintained its most landward position marked by the relict overwash fan (Fig. 5A-C). Once the inlet had closed, the system reverted to its previous morphodynamic behavior by establishing an inlet in the south (Fig. 5B).

\section{DISCUSSION}

\section{Seasonal morphodynamics}

The seasonal inlet/barrier morphodynamics described herein closely resemble those described for other river-dominated estuaries (Cooper, 2001; 2002). The breaching of the inlet is controlled by the back-barrier water elevation which becomes perched during the wet season. In contrast to some other riverdominated systems (e.g. Green et al., 2012), overwashing does not cut a channel in the barrier causing a breach; instead this process supplements the closure of the inlet. The typical breach response of these systems involves the development of a poorly developed ebb-tide delta or ephemeral mouth bar (Cooper, 1990) that is reworked into the barrier causing inlet closure. Bezerra et al. (2011) document similar responses by other ephemeral inlets; whereby opening of the inlet is proceeded by onshore movement of sediment and gradual closure of the system, though the trapping of littoral sediments supplements this closure. In the case of the Zinkwazi Estuary, this does not occur as the inlet is situated in the wave shadow of the headland in a zone of littoral bypass.

The association of closed inlet states with extensive washover fans in the backbarrier indicates that closure is likely related to washover that plugs the inlet. This is typical of ephemeral inlet behavior in closed headland embayments along the KwaZuluNatal coast (Cooper, 1994). Studies from similar scale inlets with similar tidal regimes (e.g. New South Wales Australia) do not recognize overwash as a mechanism for backbarrier infilling and inlet closure (cf Morris and Turner, 2010). Rather, stormy conditions cause the growth of tidal shoals in the mouth of the system and elongation of the inlet form. In the case of the Zinkwazi Estuary, the dearth of flood tide deltas and the tendency for the back-barrier to evolve to planform state over decadal time scales indicates the dominance of both fluvial reworking during flood events (Cooper et al., 1989; Cooper, 1994) and wind-wave reworking of the lagoonal water body during inlet closure (e.g. Ashton et al., 2009).

\section{Episodic morphodynamics}

The March 2007 storm surge presented a unique situation whereby extreme amounts of marine sediment were introduced to the system causing the rollover of the barrier by $\sim 100 \mathrm{~m}$. The degree of rollover far exceeded the typical seasonal variation in the barrier width and position. Prior to rollover, the inlet positioning was dictated by elevated bedrock and barrier thinning at the southern headland. After rollover, the reorganization of the barrier caused an entirely new set of morphodynamic processes to occur.

In effect, a morphodynamic threshold was crossed whereby a new sub-surface geology was encountered (the absence of bedrock where the new inlet was located in the middle of the barrier) and 
deeper scouring of the inlet was promoted. The dramatic thickening of the barrier to the south, the diversion of the inlet northwards and the protracted emptying of the back-barrier lagoon all comprise episodic responses to this rollover.Despite the reversion of the inlet back to its ordinary seasonal behavior, the barrier's landward line of occupation has not changed significantly since March 2007 (Fig. 5). Back-barrier processes have not yet reworked the back-barrier into a linear planform and the March 2007 washover fan is still evident. Despite both seasonal and also episodic changes to the morphodynamic behavior of the inlet, these did not rework the barrier and the rollover shoreline has persisted.

\section{CONCLUSIONS}

Ordinary seasonal variation of the inlet state is dominated by elevating the back-barrier water levels till breaching is achieved. Closure is related to washover plugging of the inlet. Once closed the system appears to achieve back-barrier planform by wind and wave reworking of the landward margin of the barrier.

Unprecedented amounts of rollover occurred in response to an extreme storm surge event. The inlet was diverted from its usual position to a new, deeper position allowing more water to be emptied from the back-barrier lagoon. The landward shoreline of the barrier has maintained its position since then. Despite reversion to seasonal processes, this rollover shoreline appears to be a persistent feature in the system.

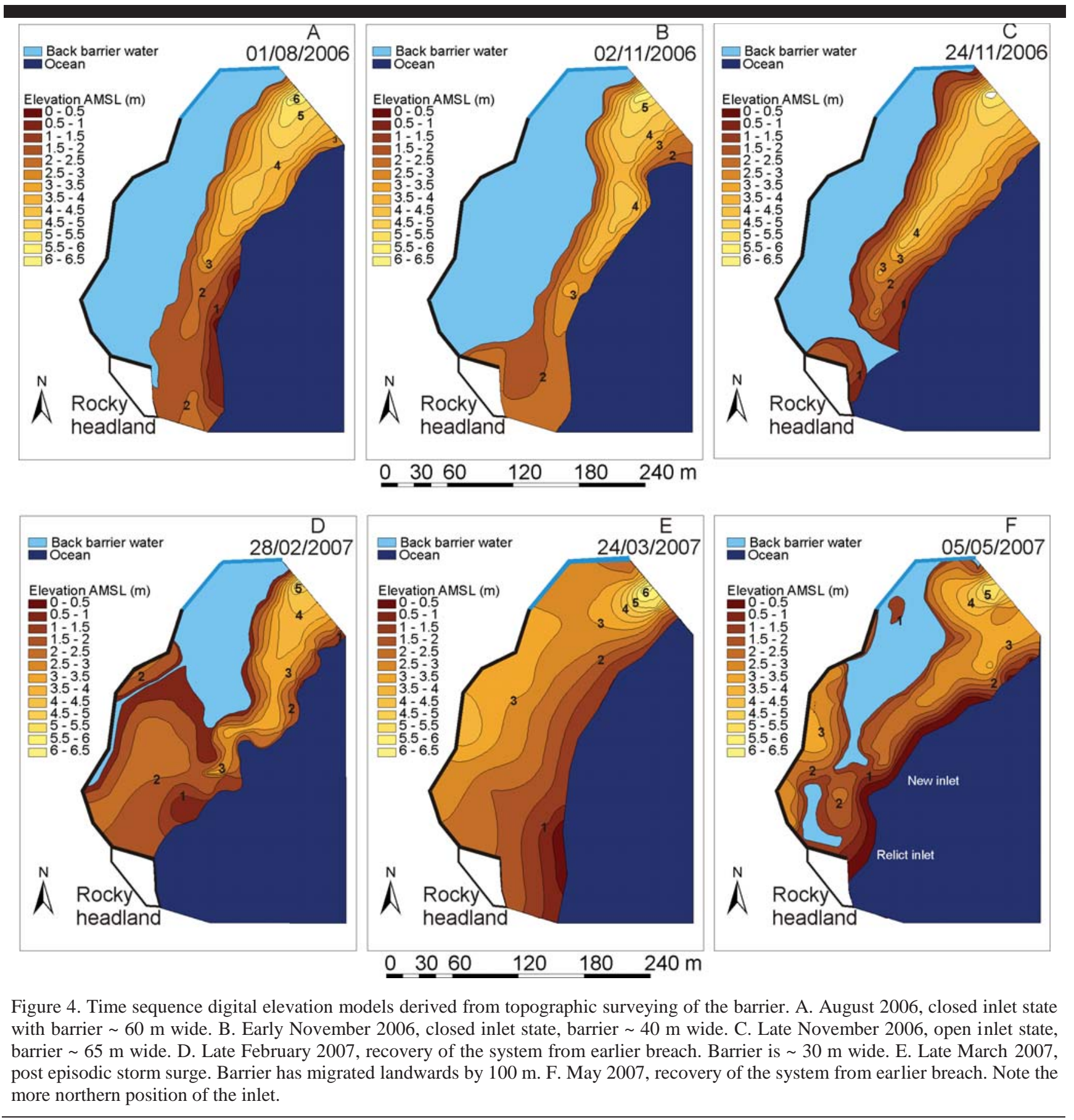



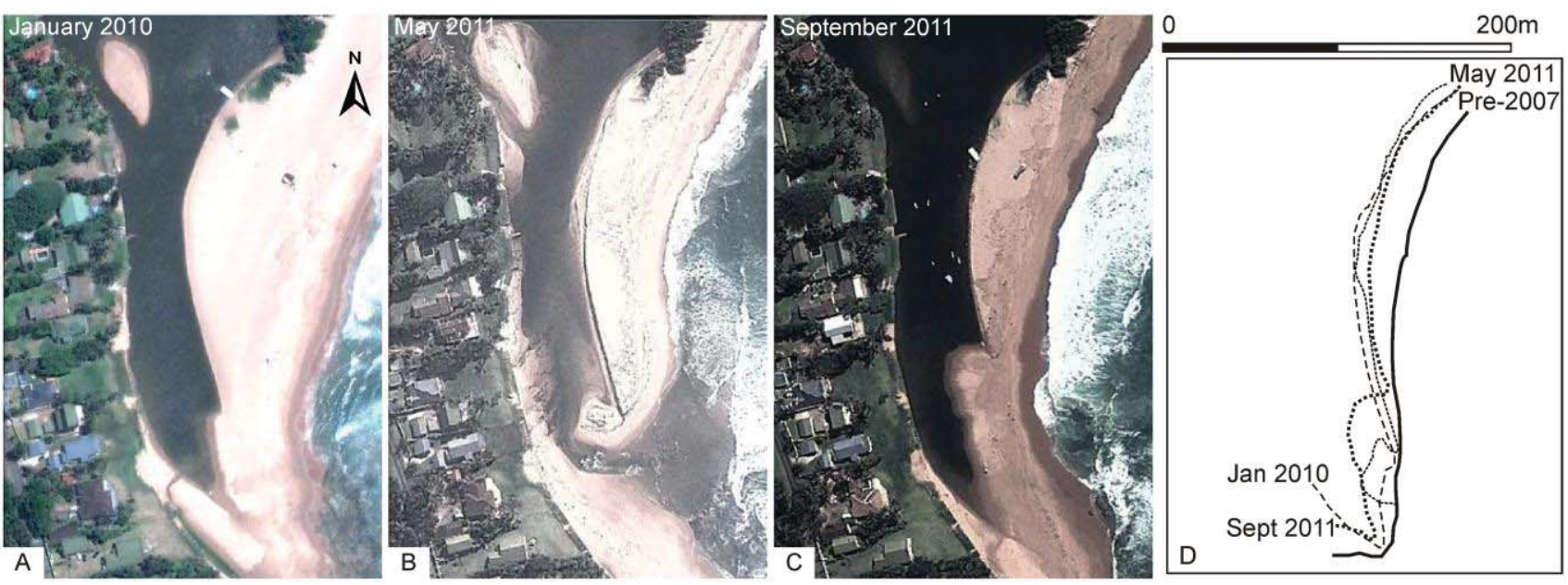

Figure 5. Post 2007 inlet and barrier configuration. (A) January 2010. Note the barrier width and evidence for a recently closed inlet in the south. (B) May 2011 with an inlet open to the south. (C) September 2011. Note the inlet is closed with evidence for its previous position to the south. Note the continued persistence of the relict washover fan marking the landward limit of the barrier. (D) Landward barrier shoreline positions since 2007.

\section{LITERATURE CITED}

Ashton, A.D., Murray, A.B., Littlewood, R., Lewis, D.A. and Hong P., 2009. Fetch-limited self-organization of elongate water bodies. Geology, 37, 187-190.

Begg, G., 1978. The Estuaries of Natal. Natal Town and Regional Planning Report. The Natal Town and Regional Planning Commission, Pietermaritzburg, South Africa, 657p.

Bezerra, M., Ferreira, Ó., Pacheco, A., Freitas, M.C., Pires, R., Andrade, C., and Taborda, R., 2011. Stages in the evolution of an ephemeral tida inlet immediately after artificial opening. Journal of Coastal Research, SI64, 1453-1456.

Bruun, P., 1962. Sea-level rise as a cause of shore erosion. Journal of Waterways Harbors Division, American Society of Civil Engineers, 88: 117-130.

Chew, J.A. and Bowen, 1971. The water resources of the coastal areas of northern Natal and Zululand. The Natal Town and Regional Planning Commission, Pietermaritzburg, South Africa, 74p.

Cooper, J.A.G., 1990. Ephemeral stream-mouth bars at flood-breach river mouths: comparison with ebb-tidal deltas at barrier inlets. Marine Geology, 95, 57-70.

Cooper, J.A.G., 1991. Sedimentary models and geomorphological classification of river mouths on a subtropical, wave-dominated coast, Natal, South Africa. Durban, South Africa: Ph.D. Thesis, 401p.

Cooper, J.A.G., 1993. Sedimentation in a river-dominated estuary. Sedimentology, 40, 979-1017.

Cooper, J.A.G., 1994. Sedimentation in the river-dominated Mvoti estuary, South Africa. Geomorphology, 9, 4, 271-300.

Cooper, J.A.G., 2001. Gemorphological variability among microtidal estuaries from the wave-dominated South African coast. Geomorphology, 40, 99-122.

Cooper, J.A.G., 2002. The role of extreme floods in estuary-coastal behaviour: contrasts bewtween river-and tide dominated microtidal estuaries. Sedimentary Geology, 150: 123-137.

Cooper, J.A.G., 2007. Temperate coastal environments. In: Perry, C. and Taylor, K. (eds), Environmental sedimentology. Blackwell publishing, pp. 263-301.

Cooper, J.A.G., Mason, T.R., Reddering, J.S.V. and Illenberger, W.I., 1989. Geomorphological effects of catastrophic fluvial flooding on a small subtropical estuary. Earth Surface Processes and Landforms, 15, 25-41.

Davis, R.A. and Hayes, M.O., 1984. What is a wave-dominated coast? Marine Geology, 60, 313-329.

FitzGerald, D.M., Buynevich, I.V., Davis, R.A. Jr. and Fenster, M.S., 2002. New England tidal inlets with special reference to riverine associated inlet systems. Geomorphology, 48, 179-208.
FitzGerald, D.M. and Nummedal, D., 1983. Response Characteristics of an Ebb-Dominated Tidal Inlet Channel. Journal of Sedimentary Petrology, 53, 833-845.

FitzGerald, D.M., 1996. Geomorphic variability and morphologic and sedimentologic controls on tidal inlets. Journal of Coastal Research, SI 23, 47-71.

Green, A.N., Cooper, J.A.G. and Le Vieux, A.M., 2012. Unusual barrier/inlet behavior associated with active coastal progradation and river-dominated estuaries. Journal of Coastal Research, in press.

McCormick, S., Cooper, J.A.G., and Mason, T.R., 1992. Fluvial sediment yield to the Natal coast: a review. South African Journal of Aquatic Sciences, 18, 74-88.

Moes, H. and Rossouw, M., 2008. Considerations for the utilization of wave power around South Africa. Workshop on Ocean Energy, Centre for Renewable and Sustainable Energy Studies, Stellenbosch, 21 February 2008.

Morris, B.D. and Turber, I.L., 2010. Morphodynamics of intermittently open-closed coastal lagoon entrances: new insights and a conceptual model. Marine Geology, 271, 55-66.

Rampino, M.R. and Sanders, J.E., 1980. Holocene transgression in southcentral Long Island, New York. Journal of Sedimentary Petrology, 50, 1063-1080.

Rampino, M.R. and Sanders, J.E., 1982. Holocene transgression in southcentral Long Island, New York: reply. Journal of Sedimentary Petrology, 52, 1020-1025.

Rooseboom, A., 1975. Sediment produksiekaart vir Suid- Afrika, Department of Water Affairs. Department of Water Affairs and Environmental Conservation Technical report, 61.

Roussouw, J., 1989. Design waves for the South African coastline. Stellenbosch, South Africa: University of Stellenbosch, Ph.D. Thesis, 169p.

Salzmann, L. and Green, A.N., 2012. Boulder emplacement on a tectonically stable, wave-dominated coastline, Mission Rocks, northern KwaZulu-Natal, South Africa. Marine Geology, 323-325, 95-106.

Schoonees, J.S., 2000. Annual variation in the net long-shore sediment transport rate. Coastal Engineering. 40, 141-160.

Smith, A., Mather, A., Guastella, L., Cooper, J.A.G., Ramsay, P.J., and Theron, A., 2010. Contrasting styles of swell-driven coastal erosion: examples from KwaZulu-Natal, South Africa. Geological Magazine, 147, 940-953. 